\title{
REVIEW ON PROJECT MANAGEMENT FUNCTIONS AND COST MANAGEMENT PROCESSES FOR DAIRY COOPERATIVES
}

\author{
Dr. Annapoorna M.S. \\ Professor, CMR University, India \\ Pramod Kumar
}

Research Scholar, Rani Channamma University, Belgavi, India

\begin{abstract}
Project Management deals with methodologies for managing projects through an integrated approach. Knowledge, skills, tools and techniques are applied to meet project requirements. The phases include initiation, planning, execution, controlling and closing. Each phase implements relevant processes such as strategy formulation, planning, managing execution, analysing results and suggesting corrective steps. The development of project plan initially defines the scope of the project along with cost, resources, timeline, quality and procurement plans. The baselines and performance measures are essential for appropriate working of the project. The schedule and cost form integral part of planning. Cost management constitute one of the major components of project management. The processes involved in project cost management are cost management planning, cost estimation, cost budgeting and cost control.

A transformation in society is initiated through cooperative programs. The socioeconomic conditions are the basis for introducing changes. Typical projects in cooperative sectors are setting up cooperatives, initiatives for enhancing growth, expansion of society, diversification of business, training \& development and projects in specific governmental programs. It is required to promote research activities for higher efficiency and performance in management functions. A structured approach is necessary for cooperative organizations engaged in dairy production and processing. In this paper, an attempt has been made to investigate the project management functions and cost management processes across cooperatives. In particular, dairy cooperatives have been analysed to identify well-designed notion.
\end{abstract}

Keywords: Dairy cooperatives, Project planning, Project control, Cost management plan development, Cost estimation, Cost budgeting, Cost control.

Cite this Article: Dr. Annapoorna and Pramod Kumar, Review on Project Management Functions and Cost Management Processes for Dairy Cooperatives, Journal of Management (JOM), 6 (5), 2019, pp. 1-9.

http://www.iaeme.com/JOM/issues.asp?JType=JOM\&VType=6\&IType=5 


\section{INTRODUCTION}

Higher profitability of organizations is achieved by successful completion of projects. The application of contemporary management processes is essential to achieve success, even with financial constraints, resource constraints and limitation of time. Failure to meet project objectives leads to loss of profitability of organizations. Uncertainty in management processes and techniques lead to failure in achieving project objectives which incur business losses. The reasons of failures include geographical challenges, social issues, economic constraints as well as lack of professionalized management. The management maturity affects project success and failure. This has a direct impact on economic growth of an organization. Industry experiences and historical data show that many cooperatives programs either do not deliver the desired endresults or get terminated prematurely. This problematic situation needs an immediate solution for enhancing development opportunities of the cooperative sector.

Major source of income in rural India is agriculture and dairy farming. Rural population is mainly involved in the production and marketing at different levels. New technologies with appropriate project management processes prove revolutionary measures to improve the level of production with quality of above activities. The scheme of 'White Revolution' has been adopted by dairy cooperatives to result in growth of their federations at district and state level. Numerous districts in the country have established District Cooperative Milk Unions. The accomplishment of milk processing activities is a result of successfully managed project in dairy cooperatives. There is a definite upgradation in the system procedures and operations of dairy cooperatives by practicing project management processes.

It is required to design a suitable management framework by undertaking research activities. The principles and techniques of management have proved essential for successful operation of business organizations [1]. The adoption of contemporary cost management processes would certainly enhance the progress prospective to match up with challenges posed by current business environment. The outcome of research provides improved efficiency and enhanced performance in management functions leading to stronger and more competitive cooperative organizations.

Cooperative projects are undertaken in economic activities such as agriculture, milk production, sugar processing, consumer supplies, marketing, handloom, handicraft, housing, fertilizer production, transport and communication. Typical projects in cooperative sectors are setting up cooperatives, expansion of society, diversification of business function, initiatives for enhancing growth, training and development and projects in specific governmental programs. The projects are envisioned as business functions. The application of standard management processes is significant for efficient execution of projects. It is necessary to follow a systematic approach for all phases of project management.

\section{NEED FOR THE STUDY}

Cooperative business organizations face tough competitions in marketplace as well as subjected to financial constraints, resource constraints and limitation of time. There have been considerable cases of troubled projects due to lack of systematic study and mismanagement. Failures are attributed to characteristics of teams, material, technology, product quality and market conditions. The dairy cooperatives are extremely susceptible to geographical, social and economic constraints. Simultaneously, uncertainty in management techniques and processes lead to business losses. The variations in budget, scope and business rules are aspects for consideration. Keeping in mind the above challenges, the present work makes a study on existing project management processes such as initiation, planning, execution, control and closure with reference to dairy cooperatives. The investigation helps understand the application of contemporary project management standards at various levels in cooperative societies. It is 
required to establish a correlation of project phases with challenges. Cooperatives are considered as democratic institutions for several decades. The present development of cooperative operations has created a need for professionalized management. The role of democratic structure along with induction of professional project management, ensures improved economic growth and enhanced efficiency in the cooperative projects. It is essential to incorporate cost management aspects of value analysis, risk analysis, quality and resources. This ensures preparedness to face tough competition in marketplace due to environment of globalization.

\section{PROJECT MANAGEMENT FUNCTIONS}

The successful completion of project requires a set of standards and practices applied to the planning and execution. The elements include accomplishment of project, deliverables generation, reviews, control, approval and people. In order to meet the requirements of the project, knowledge, skills, tools and techniques are applied to a wide range of activities [17].

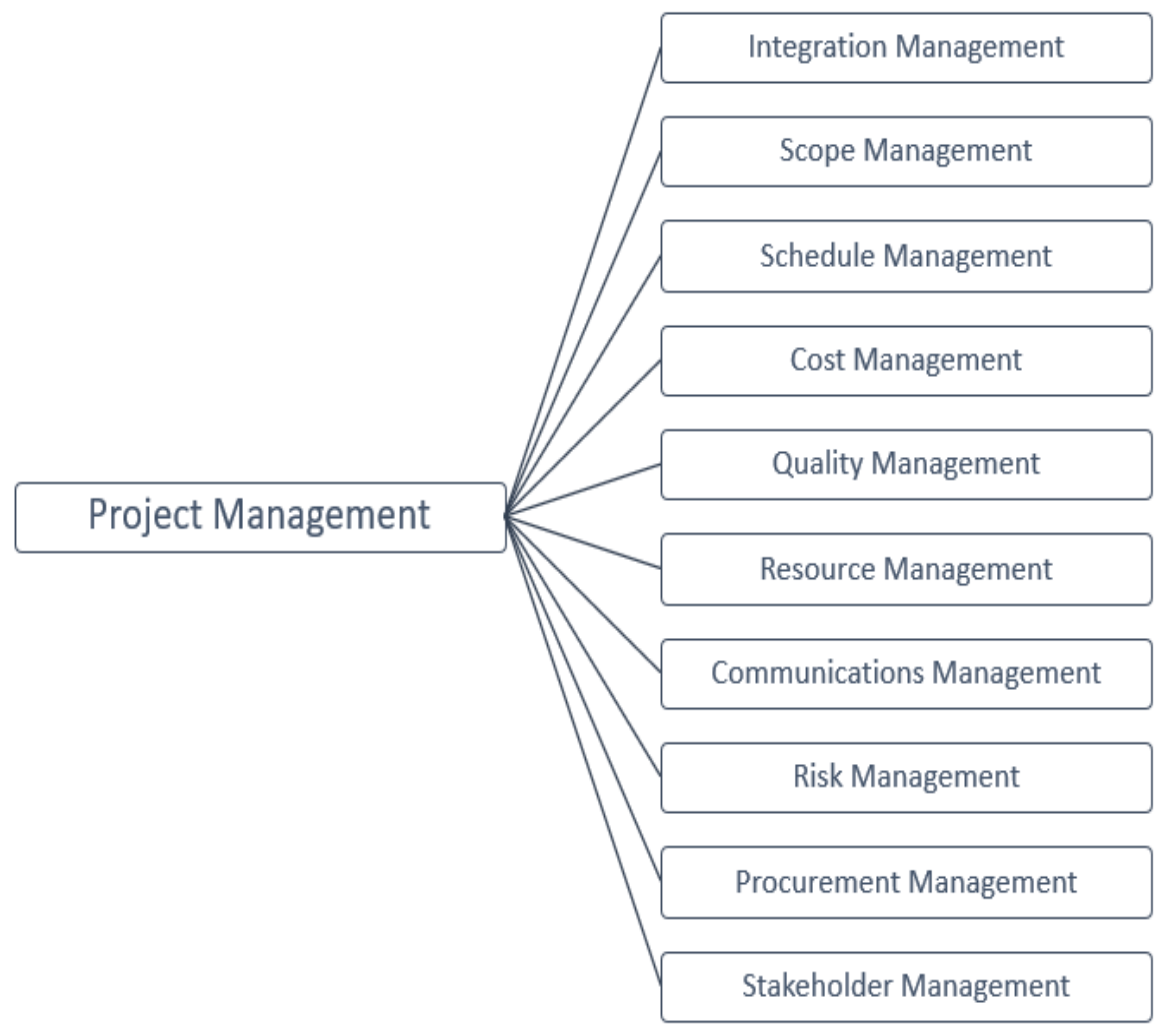

Figure 1. Project Management

Initiation, planning, execution, controlling and closing are identified as the phases of project management lifecycle. The phases of project management constitute a pathway to accomplish the project requirements as shown in Fig. 1.

Initiation: Initiation phase is the start of the project. The project objectives are defined and ensured to be specific, measurable, attainable, realistic and time bound. The project definition and statement of work is specified at a broad level. A business case, business needs are analysed for feasibility and project stakeholders are identified.

Planning: Planning phase focuses on developing roadmap. The goals are set to obtain a clear understanding of the process. Detailed scope definition, schedule, costing, budgeting is performed. Quality plan, risk management plan, human resources plan, communication plan 
and procurement plans are created. It is essential that all the plans are integrated and are in synch.

Execution: Execution phase involves a sequence of activities to develop and complete deliverables. The teams carry out their responsibilities and generate data for further reporting. The set of tasks executed are framing of teams, assigning resources, executing work as planned, procurement, perform task assignments, project schedule updates and modification of project plan as per requirement.

Monitoring and Controlling: Monitoring and Controlling phase measures the progress and performance to ensure that tasks are executed as per project management plan. The team provides status reports, development updates and performance reports. Key performance indicators aid to determine the progress of the project.

Closure: Closure phase signifies completed project. Final deliveries are done acceptance is received. The collection of documents and deliverables is performed with final reports. The accomplishments during project is appreciated and valuable team members are recognized. A discussion of possible success and failure help in identifying the areas of improvement for future endeavours. All lessons learned are recorded in closure phase.

\section{COST MANAGEMENT PROCESSES}

Cost management constitute one of the major components of project management. The processes involved in project cost management are cost management plan development, cost estimation, cost budgeting and cost control as shown in Fig. 2.

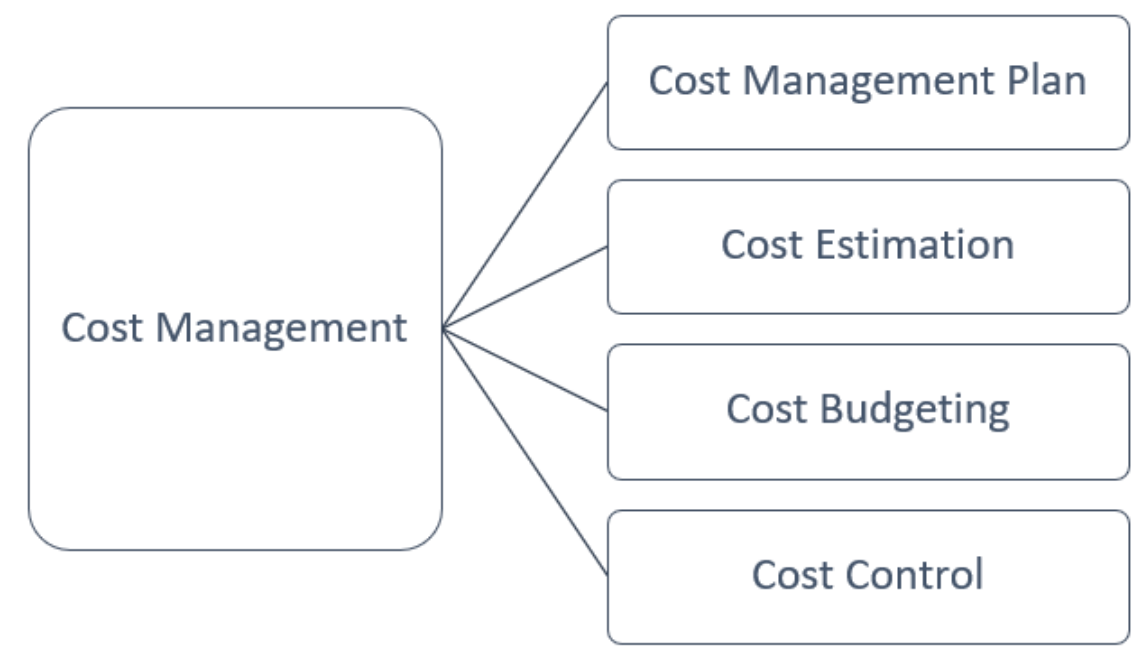

Figure 2. Project Cost Management

Cost Management Planning: The first process, cost management plan development is to create the plan. The focus points for the plan are planning the cost to project, supervising the project to the cost, controlling the cost, manage the cost variances and proactive thinking. The steps for design of the plan include, Statement of cost estimate, Accuracy levels, Directions for estimating cost performance in terms of identification, tracking and reporting, Formats for reporting, Split-up of direct and indirect costs, Limits for cost expenditure and Modify control actions for changes incurred in cost.

Cost Estimation: Cost estimation is proportional to each identified activity of the process. The costs are measured in terms of direct cost, indirect cost, overhead cost, resources, project management activities, quality efforts and risk efforts. Scope baseline determines the project 
scope and intimates the project manager to identify the activities in scope and out-of-scope. The cost directly allocated to the work carried out in the project is the direct cost. Indirect cost cannot be assigned to a specific project instead is used for multiple projects. There are several guidelines for estimating the cost. Resource plan contains details on number of project members, resources and relevant cost. Risk register is the major contributor in decreasing the cost and time span associated with the project. The cost calculations and estimations can be computed easily using historical records obtained from previously executed projects. The marketplace conditions and cost for commercials contribute to the cost estimation. The expenses on execution of project manager, status reports, execution, change analysis add on to the estimation. The approach of bottom-up estimation involves the cost estimation for each activity, moving upwards into control units and finally to overall project.

Cost Budgeting: Project schedule encompasses the activities with allocated resources and timeline. The schedule and cost are interdependent in many cases.

For effective cost management, it is essential to analyse cost of project activities in reference with project schedule. Cost budgeting is preparing cash-flow requirements for the project against the timeline. Reconciliation of project cash-flow requirement and funding-limit of the organization is essential to prepare a project budget. The cash-flow requirements can be optimized by rearranging the schedule depending on resources.

Cost Control: The control process supervises the cost of the project. The cost management plan, organization policies, tools, procedures, reporting formats provides the basis for control of the project cost. The progress reporting could follow any of the following techniques: 50/50 Rule, 20/80 Rule, 0/100 Rule. For instance, 20/80 Rule depicts the activity is considered 20\% complete during starting and gets credit for the rest $80 \%$ only on completion.

\section{LITERATURE REVIEW}

The review of literature concentrates on project management functions and cost management processes for dairy cooperatives. Rural population in India depend mainly on dairying as a major source of income. Several revolutionary measures have been taken up to improve the production level of milk. The schemes adopted resulted in organization and development of dairy cooperatives and federations at district and state levels. Districts across the country have established dairy cooperative milk unions to undertake the projects.

A successful project requires well planned processing and marketing activities. The procedures and operations require upgradation by practicing the concepts of project management. A framework is designed to implement processes and standards. Planning, scheduling, monitoring resource utilization, tracking progress, administering the budget, performing quality reviews and maintaining documentation are the functions identified. The demand for milk initiates creation of adequate infrastructure for procurement, processing and preservation. Milk production is increased by providing technical and financial support. Strengthening of cooperatives is possible through quality regulation, order undertaking, market environment and state support. Sustainable production of milk is possible by understanding cooperative solutions and arrangements. The correlational dependency is represented based on projects and capital investment. The key points of the existing literature is provided as follows:

- Dairying has been an important source of income generation for millions of families in rural India. Notable ventures during pre-independence include Kaira District Cooperative Milk Producers' Union Limited of Anand, Gujarat. The post-independence endeavour is the setup of National Dairy Development Board leading to transformation of India as world's largest milk producer. The dairy cooperatives were an integral part of major program called Operation Flood. Karnataka has a vital role in promoting milk and dairy production in India. Dairy production 
has seen tremendous growth due to policy decisions taken up for methodical breeding, structured feeding and high-quality health care management. Dairy sector is promising arena to inflate the socio-economic status of milk producing farmers [2].

- Cooperatives exist as business institutions with social and religious orientation to cater the community needs [3]. Cooperatives respond to the felt-needs of the members through devoted management that can provide security and satisfaction. The farmer's cooperatives market the quality farm input to accomplish substantial returns. Worker's cooperative make employment available on acceptable terms. Housing cooperatives facilitate quality housing at reasonable cost. Credit cooperatives assist facilities for saving and borrowing at fair rates of interest. Dairy cooperatives offer timely services and market to milk producers. In general, the cooperatives strengthen individuals to acquire and control certain belongings by preserving individual selfesteem and concern. Few examples of cooperatives across India are Indian Farmer's Fertilizer Cooperative Limited, Padmashree Dr. Vithalrao Vikhe Patil Cooperative Sugar Factory Limited and Kaira District Milk Producers Cooperative Union Limited (AMUL).

- There is a general observation to categorize cooperatives based on service and production [4]. The evaluation of practices and cooperative capabilities are required for scenario modeling. The collection and evaluation of demographic, ownership, income, spending, savings production and processing data prove the purpose of cooperatives. A structured questionnaire and face-toface interviews form the basis for data collection. The assessment is achieved using previously collected data and reported differences.

- The cooperative structure has been serving the Indian society since 1904 with the mechanisms for development programs [5]. Substantial progress in cooperative movement has been observed after independence through the establishment of All India Rural Credit Survey, Working Group on Industrial Cooperatives, M.L. Dantwala Committee, Working Group on Cooperation for the Fifth Five Year Plan, Capoor Committee and Vaidyanathan Committee. The working of Planning Commission emphasized the rationale for cooperative movement during the five-year plans.

- It has been observed that dairy farming has been the second most important income-generating element [6]. A group of at least 25 milk producing farmers define dairy cooperatives that form collective income generation. A case study was conducted on Adarsha Milk Producer Dairy Cooperative, Mahuli, Saptari district of Nepal and it was identified as highest income contributor of $55 \%$ to the rural farmers. Economic and social impacts were analysed. The economic impact deals with financial achievement from dairying such as animal sale, milk cash, fertilizer, draught, Bio-gas and employment. Social impact deals with their links in achievement of whole society such as education, health, communication, eco-financial, environment and employment. The primary data was collected via questionnaire, interview and field observation.

- The dairy development activities by Bangladesh Milk Producer's Cooperative Limited over the last 30 years has proven a remarkable impact on milk production [7]. The expansion of milk sheds, number of cooperatives, vaccination, treatment facilities, cross breed cows has contributed to more than $60 \%$ of total marketed milk in Bangladesh. Field survey was used to collect primary data. The secondary data collection was based on milk collection, milk price, nature of dairy cows, loss and profit incurred. The facilities such as vaccination, treatment and cross breed cows augmented to the quality of dairy cows leading to major marketed milk in the country.

- The association of market participants with cooperatives has been dealt through transaction governance [8]. The role of cooperatives was based on marketing functions such as bargaining, niche marketing, fluid processing and diversified. The transaction governance analysis presents the unique cooperative structure, organization, governance, equity financing and economics. The equities of dairy cooperatives are grouped into miniscule portion of total equities, retained patronage refunds, earnings from non-member businesses, appealing portion of dairy 
cooperative equities. There is general observation of cooperatives being adapted to various governance modes.

- The recovery and growth of overall dairy chain in Karnataka has been studied along with the outcomes of milk cooperative development program [9]. The institutions engaged in dairying in Karnataka at primary level is Primary Milk Producers Co-operative Societies at Rural level., secondary level is District level: District Co-operative Milk Producers Union Ltd., and at state level is Karnataka State Cooperative Milk Producers Federation Limited, Bangalore. (K.M.F). The activities were implemented through 13 district milk unions. The scope of study importantly include livestock holding, land holding, milk production, market strategies, migration, school dropouts and malnutrition. The secondary data considered was records, registers and reports of milk unions and department of Animal Husbandry.

- Milk marketing depends on structure of the market, spread of price, cost and efficiency [10]. Considering four districts from Andhra Pradesh, three categories of milk sellers were identified based on the number of animals. The challenges include quality, product development, infrastructure support development and global marketing,

- A descriptive, evaluative and analytical study has been carried out on cooperative situation in Bangladesh [11]. The primary source of data is the questionnaire collected from cooperatives running their operations in Dhaka. The secondary sources of data include newsletters, websites, newspaper, journals, articles etc. The prospects of improvement are education \& training for development of management and business skill, relevant advisory services, finance assistance, promotional activities and periodic campaign program.

- A preliminary study on value chain of liquid milk in Bengaluru rural was conducted to strengthen and sustain its performance [12]. Chain wide learning methodology was adopted to identify issues, opportunities and importance of stakeholders. The competitive strength, weakness, opportunities and threats were analysed using value chain analysis based on supplier, milk producer, collection centers, chilling centers, processing plant and milk parlours. The mapping facilitates the identification of main actors, core process, stakeholders and support services.

- Ignacio Bretos et. al., explored the challenges faced by worker cooperatives at multinational horizon [13]. The judgement is deduced by analysis of capitalist and cooperative strategies. The multi-nationalization process of worker cooperatives has been examined to analyse the autonomy in subsidiary and mapping of typical human resources practices to foreign subsidiaries. The work also provides an indication of disconnection between managerial discourse and implementation of practices within foreign subsidiaries. The study on two multinational co-ops from Mondragon Cooperative Corporation has been carried out to understand the dynamics of central control, constraints and issues pertaining to cooperative model.

- An economic analysis of dairy farming based on costs and returns was conducted in Bikaner district of Rajasthan [14]. The management practices under consideration were feeding of fodder, cleaning of animals \& animal shed, salt \& watering, deworming, artificial insemination and vaccination. The cost concepts included feeding cost, labor cost, fixed cost, depreciation on animals, depreciation on capital investment, interest on fixed capital, total cost, net cost, lactation-length, dry-period, inter-calving period. Major portion of the cost was accounted for feed and fodder. The input-output ratio at the overall level was estimated as 1.58.

- The budgetary system implemented at Hassan Co-operative Milk Producers Societies Union Limited was studied to compute and analyse the variances for control and performance measures [15]. The primary source of data was from managers, accountants and officials from accounts department. The secondary data was gathered from accounting records, magazines, journals and related publications. The process obtains estimates of sales, production levels, expected costs and availability of resources. The estimation is communicated to responsible managers for 
planning and implementation. The budgets are prepared for sales, production, material, labour, inventories, administration, cash and capital expenditure. The particulars for cost estimation include purchases, procurement, transportation, processing, manufacturing, staff, marketing and distribution.

- A good budgetary control and management of marketing, finance, production and personnel is essential for successful cooperative [16]. The fund management at Coimbatore District CoOperative Milk Producer's Union Limited was studied. The financial statements were interpreted for ratio analysis, correlation and operating expenditure estimate. The parameters for ratio analysis were operations, capital turnover, fixed asset, stock turnover, fixed asset and proprietary values.

\section{CONCLUSION}

The application of contemporary management concepts is the only potential recourse to achieve success, even with financial constraints, resource constraints and limitation of time. Industry experiences and historical data show that a comprehensive solution is required for enhancing growth opportunities of the cooperative sector. The initiatives are based on business, environmental, technical and financial challenges. The activities highlight projects that require consistent process driven approach. Application of standard management processes are essential for efficient execution of projects. Project management functions and cost management processes are identified for successful delivery of products and services in the market. The present investigations aid to present these aspects for dairy cooperatives. The survey provides a know-how on existing processes which would further lead to design a model for effective implementation of project management life cycle.

\section{REFERENCES}

[1] Sah A.K., Professional Management for the Cooperatives, Vani Educational Books, 1984.

[2] Lipismita Samal and A. K. Pattanaik, Dairy Production in India - Existing Scenario and Future Prospects, International Journal of Livestock Research, Vol. 4, Issue 2, May 2014.

[3] Dr Daman Prakash, Enlightened Cooperatives inculcate Social Cohesion and Harmony, http://ica-ap.coop/sites/ica-ap.coop/files/articles_16.pdf.

[4] Vladimir Milovanovic and Lubos Smutka, "Cooperative rice farming within rural Bangladesh", Journal of Co-operative Organization and Management, Vol. 6, pp. 11-19, 2018.

[5] Anil Kumar Soni and Harjinder Pal Singh Saluja, A Study on Development of Cooperative Movement in Planned Economy, International Journal of Economics, Commerce and Research, Vol. 3, Issue 1, PP. 39-48, March 2013.

[6] Balak Chaudhary and Mukul Upadhyaya, Socio-Economic Impacts of Dairy Cooperative, Economic Journal of Development Issues, Vol. 15 \& 16, No. 1-2, Combined Issue, pp. 1523, 2013.

[7] Ashoke Kumar and Keshav Lall Maharjan, Development of Dairy Cooperative and Its Impacts on Milk Production and Household Income: A Study on Bangladesh Milk Producers'Cooperative Union Limited, Journal of International Development and Cooperation, Vol.10, No.2, pp. 193-208, 2004.

[8] K Charles Ling, The Nature of the Cooperative: A Dairy Cooperative Case Study, USDA Rural Development, Research Report 224, April 2012.

[9] Sreenivasaiah K and Dr. J A Arul Chellakumar, Role Of Milk Cooperatives In Village Development Of Karnataka State, IOSR Journal of Business and Management, Vol. 18, Issue 8, Ver. 1, pp. 23-29, Aug 2016. 
Review on Project Management Functions and Cost Management Processes for Dairy Cooperatives

[10] R.V.Sujatha, T.Suseela and K.Suseela, Milk Marketing in Co-operative sector and Private sector in Andhra Pradesh, India: A Comparative study, International Journal of Scientific and Research Publications, Vol. 5, Issue 12, pp. 401-406, December 2015.

[11] Jannatul Islam, Md. Azim, Md. Mobarak Karim and Ashraful Begum, The Problems and Prospects of Co-operative Society: A case study on its evolution and future possibilities in context of Bangladesh, Vol. 10, Issue 3, October 2014.

[12] Vanishree M, Sendhil R, Smita S, AK Chauhan, Rashmi HM and Ponnusamy K, Role of Dairy Cooperatives in Strengthening Value Chain of Liquid Milk and its Sustainability in Karnataka: Findings from Preliminary Study, Indian Journal of Economics and Development, Vol. 14, Issue 1a, pp. 410-415, 2018.

[13] Ignacio Bretos and Anjel Errasti,, "The challenges of managing across borders in worker cooperatives: Insights from the Mondragon cooperative group", Journal of Co-operative Organization and Management, Vol. 6, pp. 34-42, 2018.

[14] Raju Kumawat, N. K. Singh and Chiranjee Lal Meena, Economic Analysis of Cost and Returns of Milk Production, Extent of Adoption of Recommended Management Practices on Sample Dairy Farms in Bikaner District of Rajasthan, Global Journal of Science Frontier Research: D Agriculture and Veterinary, Vol. 14, Issue 5, Version 10, 2014.

[15] A Study on Budgetary Control System conducted at Hassan Cooperative Milk Producers Societies, https://www.projectskart.com/2017/12/study-budgetary-control-system.html.

[16] Amala V Venkatasami, A Study on Budgetary Control with Special Reference to Coimbatore District Co-Operative Milk Producer's Union Limited, Coimbatore, Journal of Business \& Financial Affairs, Vol. 4, Issue 2, pp. 1-9, 2015.

[17] A Guide to the Project Management Body of Knowledge (PMBOK® Guide) - Sixth Edition, Published by Project Management Institute, Inc., USA. 